\title{
OCEANIC ENVIRONMENT OF GEORGE VI ICE SHELF, ANTARCTIC PENINSULA
}

\author{
by
}

M.H. Talbot

(British Antarctic Survey, Natural Environment Research Council, High Cross, Madingley Road, Cambridge CB3 OET, England)

\section{ABSTRACT}

A collation of available data shows that sea-water with a temperature $3{ }^{\circ} \mathrm{C}$ above the in-situ freezing point lies beneath George VI Ice Shelf in the Antarctic Peninsula, and is widespread on the Amundsen-Bellingshausen continental shelf. The presence of warm water is a factor in the recent and continuing disintegration of ice shelves in the region, yet the meteorology and oceanography of the sector are little known. We discuss a plausible link between the present climatic conditions, sea-water characteristics and the warm-water intrusion on to the continental shelf, thereby illustrating an indirect climatic influence on the mass balance of ice shelves.

\section{INTRODUCTION}

Glaciological studies on George VI Ice Shelf in the 1970 s indicated that a high basal melt rate is necessary to explain the dynamics of the ice shelf. This directed attention towards the marine environment of George VI Sound as the source of heat. Potter and others (1984) presented a coherent analysis of the mass balance of the catchment of George VI Ice Shelf and deduced an equilibrium basal melt rate of more than $2 \mathrm{~m} \mathrm{a}^{-1}$ of ice, averaged over the ice shelf. A recent oceanographic survey supports this figure (Potter and others 1988). The temperature of water at the sea floor under George VI Ice Shelf is more than $3^{\circ} \mathrm{C}$ above the in-situ freezing point, whereas beneath the Ronne and Ross ice shelves the

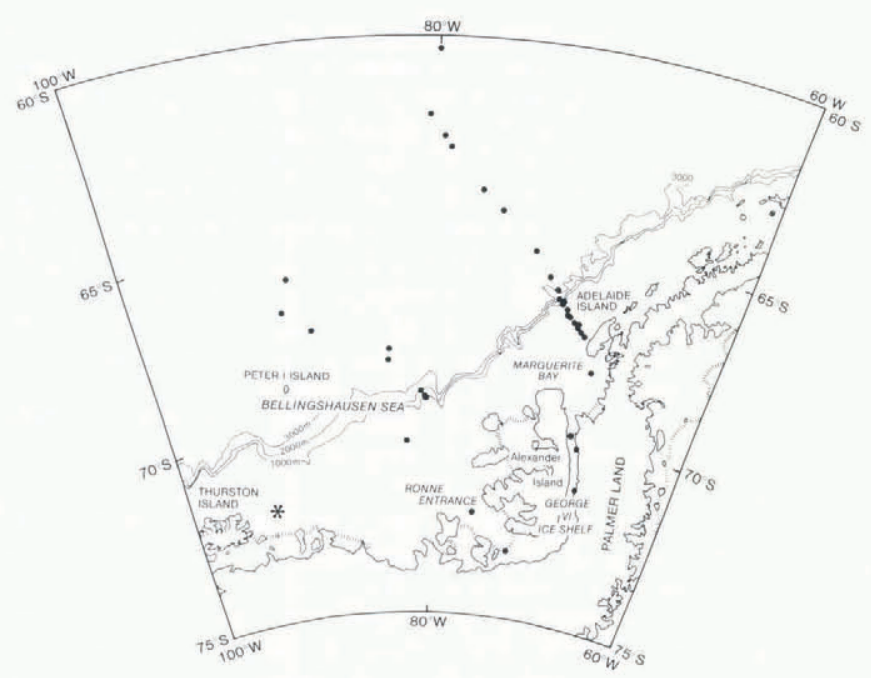

Fig. 1. Location diagram showing the 35 stations used in the sections. The asterisk marks the approximate location of the nearest hydrographic stations in the western Bellingshausen Sea. The Amundsen Sea lies to the west of Thurston Island. temperature is barely $0.5^{\circ} \mathrm{C}$ above freezing and is potentially supercooled in places (Foldvik and others 1985, Jacobs 1985).

Although detailed oceanographic work under the most closely studied, northern section of George VI Ice Shelf has revealed much about the water circulation, the broader, regional description has not advanced significantly since the classic work of Deacon (1937). Jacobs (1985) drew attention to the significance of the Amundsen-Bellingshausen coastline (Fig. 1), including the present study area, noting that it is "practically unsampled", despite its critical importance to the understanding of links between climate, continental-shelf water and the vulnerable ice shelves. In particular there is a need to investigate the presence of warm water on the continental shelf of this sector, and its potential sensitivity to climatic change.

Hydrographic sections have been published for the Weddell Sea-Ronne Ice Shelf sector (e.g. Gill 1973) and for the Ross Sea (Jacobs 1985). As a contrast to these cold ice-shelf environments, we present here sections of temperature, salinity and density which embrace George VI Ice Shelf and extend from the deep ocean across the continental-shelf break. With this information we identify the main oceanographic features of the area and discuss the reasons why George VI Sound contains warmer water than is found beneath the major Antarctic ice shelves.

\section{HYDROGRAPHIC SECTIONS}

Hydrographic sections of potential temperature $(\theta)$, salinity $(S)$ and density anomaly $\left(\sigma_{\theta}\right)$ have been prepared. The main source for sections of deep oceanic sites was the United States National Oceanographic Data Center data base (USNODC 1983). The section runs from $60^{\circ} 21^{\prime} \mathrm{S}, 79^{\circ} 54^{\prime} \mathrm{W}$ towards the south-east, on to the continental shelf and into Marguerite Bay. It continues along George VI Sound, using five profiles taken by the British Antarctic Survey, and thence towards the north-west, crossing the Bellingshausen Sea continental-shelf break, towards $66^{\circ} 0^{\prime} \mathrm{S}, 89^{\circ} 15^{\prime} \mathrm{W}$, north of Peter I Island (see Fig. 1). Stations in the open sea were projected on to the main line of the section.

\section{REGIONAL TOPOGRAPHY AND BATHYMETRY}

George VI Sound is a submerged block-faulted rift valley lying between Alexander Island and Palmer Land on the west coast of the Antarctic Peninsula. For $450 \mathrm{~km}$ of its length the channel is overlain by George VI Ice Shelf (Fig. 1). The most complete bathymetric data for the area are presented in Maslanyj (1987), figures 4 and 5 . The maximum depth of George VI Sound exceeds $800 \mathrm{~m}$ for $85 \%$ of its length. The remaining section, near the northern ice front, is deeper than $600 \mathrm{~m}$. North of Alexander Island the continental shelf is generally deeper than $500 \mathrm{~m}$ and parts of Marguerite Bay are over $1000 \mathrm{~m}$ deep. In Ronne Entrance, George VI Sound is linked with the deep ocean by water approximately $500 \mathrm{~m}$ deep (Admiralty Chart 3175). 
George VI Ice Shelf thickens from less than $110 \mathrm{~m}$ at its northern end (at $70^{\circ} \mathrm{S}$ ), to a maximum thickness exceeding $475 \mathrm{~m}$, which forms an inverted sill at the base of the ice shelf. This sill lies within $100 \mathrm{~km}$ of the southern ice front, where the axis of George VI Sound is along $73^{\circ} \mathrm{S}$. West of the basal sill, the ice shelf thins rapidly and is less than $175 \mathrm{~m}$ thick at the southern ice front.

\section{CURRENTS ON AND BEYOND THE CONTINENTAL SHELF}

Direct-current measurements from the continental shelf are mostly provided by ship-drift observations or, more recently, by tracked buoys, drifting in sea ice. Indirectly, measurements of temperature $(T)$ and salinity $(S)$ are used to compute the density or specific-volume field, from which geostrophic flow may be deduced.

In Figure 2 we present the section showing density anomaly $\left(\sigma_{\theta}\right)$ to $1000 \mathrm{~m}$ depth. In this depth range and for

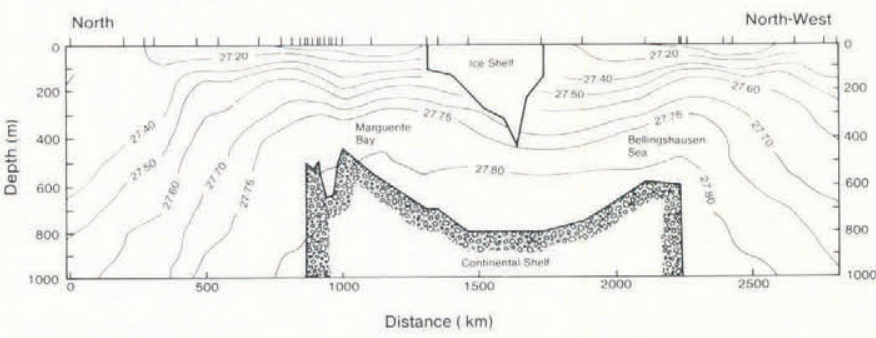

Fig. 2. Section of density anomaly $\sigma(\theta, S, 0)$ from near Drake Passage, through George VI Sound, into the Bellingshausen Sea and finishing north of Peter I Island. The positions of the stations are marked along the edge of the figure.

our purpose, $\sigma_{\theta}$ represents a reasonable approximation of the in-situ density. Although calculations of dynamic height have not been made, the implied geostrophic flow is in agreement with the more exhaustive but coarser-scale studies of Grigor'yev (1969).

In the deep water beyond the continental-shelf break. the strong horizontal density gradients, with lighter water to the north, imply an eastward flow of water. At both points in our section where the continental-shelf break is crossed (at 830 and $2200 \mathrm{~km}$ ) there is a local density maximum with respect to water at the same level to the north and south.

Moving southwards on to the continental shelf, we find that horizontal density gradients are smallest near the sea floor. If we assume a level of no motion near the sea floor, we find that geostrophic balance requires a westward flow between this level and the surface layer. For the water off Adelaide Island (830-1020 km), Deacon (1937) suggested that the observed density distribution was caused by the longshore winds piling up the light surface waters against the coast. It is unlikely, however, that the more open waters in our section to the east of Alexander Island $(2200 \mathrm{~km})$ would be similarly influenced, and thus the high fresh-water input at the surface of the Bellingshausen Sea may be responsible in part for the baroclinic flow there.

Currents in the south-east Pacific basin and Bellingshausen Sea were investigated by Deacon (1937). Using the more extensive data set which was available after the IGY, Grigor'yev (1969) investigated baroclinic flow in the Pacific sector of the Southern Ocean. It is believed that the Antarctic Circumpolar Current beyond the continental-shelf break runs towards the north-western limb of the Antarctic Peninsula, and that at about the latitude of Adelaide Island a clockwise surface circulation marks the eastern limit of the East Wind Drift in this sector. In the southern Bellingshausen Sea a westward current in about $500 \mathrm{~m}$ of water runs along the edge of the continental shelf, and near Peter I Island a northward component completes a clockwise gyre in the Bellingshausen Sea. The East Wind Drift is apparently continuous into the Amundsen Sea. Our findings, shown in Figure 2, are entirely consistent with this scheme.

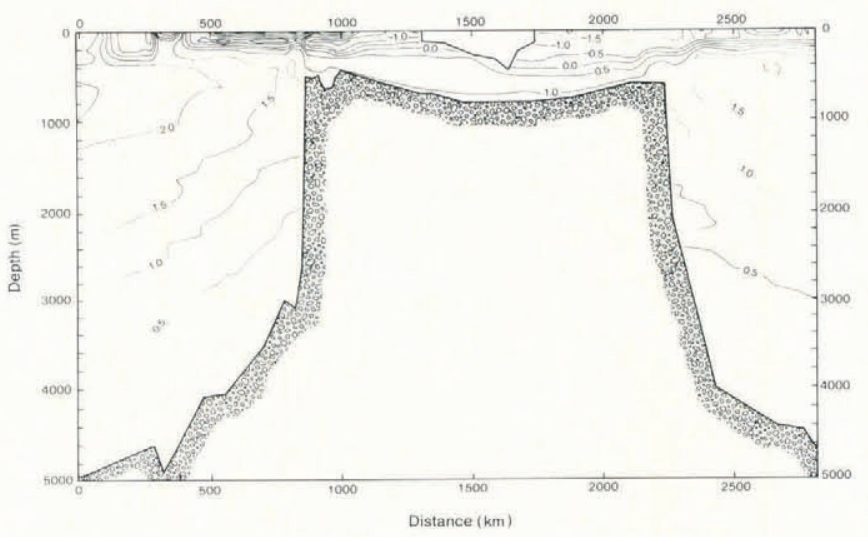

Fig. 3. Section to $5000 \mathrm{~m}$ depth, showing potential temperature, $\theta$.

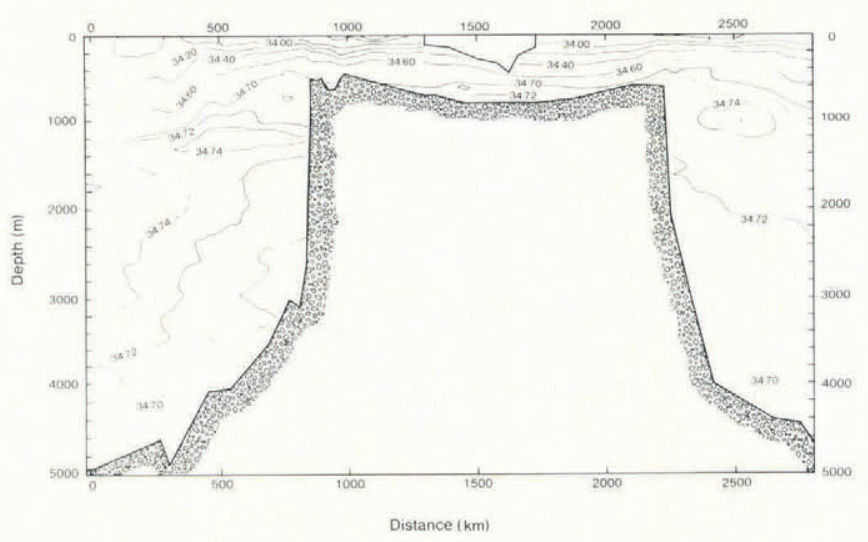

Fig. 4. Section to $5000 \mathrm{~m}$ depth, showing salinity.

\section{PROCESSES ON THE CONTINENTAL SHELF}

The temperature and salinity sections of Figures 3 and 4 clearly show that the Circumpolar Deep Water (CDW) from the south-east Pacific basin emerges on to the continental shelf and extends along the section under George VI Ice Shelf. We do not know why this happens here, whereas it fails to do so around the majority of the Antarctic coastline. The climate of the western Antarctic Peninsula and Bellingshausen Sea is unlike those of other areas where ice shelves are found.

The problem we have to solve is why the CDW intrudes on to the continental shelf, and we consider a range of explanations:

(a) The GEBCO map (Vanney and Johnson 1980) shows that the depth of the continental shelf in the Amundsen-Bellingshausen sector is not significantly greater than in other sectors of the Antarctic coastline.

(b) The convergence of $\mathrm{CDW}$ through Drake Passage and the deep circulation of CDW off the Bellingshausen Sea shelf are likely to influence conditions on the shelf. However, the CDW core off the Ross Sea continental-shelf break exhibits a similar circulation pattern and lies at similar depths. It would appear that the Amundsen-Bellingshausen sector lacks a barrier to CDW intrusion, rather than that it possesses some special characteristic which actively causes the intrusion. The contours of temperature and salinity in Figures 3 and 4 support this view.

(c) The profile of water on the Bellingshausen Sea continental shelf provides a solution. Figure 5 is a temperature-salinity diagram for water at $69^{\circ} 22.7^{\prime} \mathrm{S}$, $80^{\circ} 11.2^{\prime} \mathrm{W}$, measured by USNS Eltanin near the continental-shelf break $(2200 \mathrm{~km}$ in our sections) at the end of summer (27 March 1970). It shows a very simple mixing line on the continental shelf of the southern Bellingshausen Sea. CDW at almost $+1.2^{\circ} \mathrm{C}$ and $34.70 \%$ mixes directly with the extensive $(120 \mathrm{~m})$ surface mixed layer, whose temperature lies near the freezing point and whose salinity can be as low as $33.4 \%$. The near-freezing and highly saline shelf waters (HSSW) that elsewhere form a 


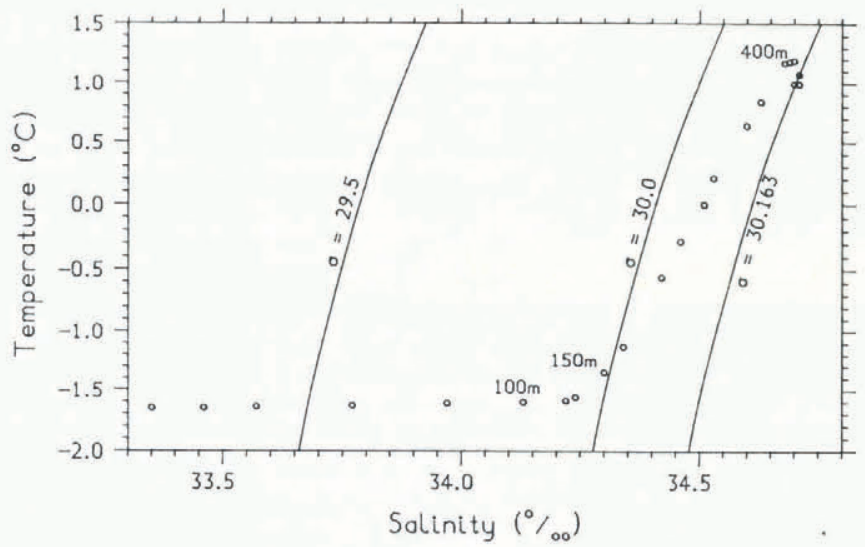

Fig. 5. In-situ temperature-salinity diagram, using data from Eltanin station $42 / 1179$. Three lines of density anomaly at $500 \mathrm{~m}$ depth, $\sigma(T, S, 500)$, are drawn, including that of the intruding CDW.

basis for bottom-water production are entirely absent. All stations located on the Bellingshausen Sea continental shelf, including those at the southern ice front of George VI Ice Shelf, show a water column similar to that in Figure 5 (U.S. Navy Hydrographic Office 1962, Potter and others 1988). HSSW has been cited as a likely cause of the blocking of warm waters at the shelf break (Jacobs 1985). The absence of the HSSW is the primary reason that warm water exists on the continental shelf. We can now show that the presence of CDW on the continental shelf is directly and simply related to the condition of the surface mixed layer.

The most likely explanation for the absence of cold dense shelf waters is that the winter formation of sea ice does not result in water dense enough to sink beneath the intruding $\mathrm{CDW}$, and that the brine release which does occur is small in quantity and offset by an unusually high freshwater input in summer. Despite the scarcity of data, we will show that this is a plausible argument.

The maximum salinity of surface water above the halocline on the Bellingshausen Sea continental shelf is between 34.20 and $34.25 \%$ (Fig. 5). Following the analysis of Gill (1973), water in this salinity range near its freezing point, and any mixture it may form with the deepest CDW on the shelf, will still be less dense than the CDW. This is easily deduced from an examination of Figure 5. We will show below that our knowledge of the climate and currents is consistent with the critically low value of the maximum surface salinity. The mean annual temperature of the western Antarctic Peninsula is about $6{ }^{\circ} \mathrm{C}$ higher than that of the eastern side (Reynolds 1981). Schwerdtfeger (1976) found a significant link between the warming west Antarctic Peninsula climate and the apparently decreasing prevalence of sea ice in Marguerite Bay. Folio 8 of the Antarctic Map Folio Series (Weyant 1967) shows a mean annual surface temperature in the Bellingshausen Sea between $-10^{\circ}$ and $-20^{\circ} \mathrm{C}$, whereas the Weddell Sea shelf is shown at less than $-20^{\circ} \mathrm{C}$ and the Ross Sea lies between $-15^{\circ}$ and $-25^{\circ} \mathrm{C}$. These higher surface temperatures support the notion of a lower rate of ice production in the Bellingshausen Sea.

The part played in salt release by leads and polynyas was highlighted by Gill (1973). However, the drift of S.Y. Belgica in the Bellingshausen Sea during the winter of 1898 (Arctowski and Mill 1908) showed no net northward drift and for much of the winter Belgica was carried back and forth parallel to the continental-shelf break. This fact, together with the known existence of multi-year sea ice in the Bellingshausen Sea (Foster 1984) implies that the net export of sea ice, which elsewhere enhances salt release and HSSW formation, is relatively small in this sector. Winter temperature profiles from the Belgica expedition show no evidence that the water column is different in winter.

Comparison of precipitation data is virtually limited to information on the number of days with precipitation. From such information, precipitation in the Bellingshausen Sea appears to be significantly higher than in the Weddell and
Ross seas. On coastal sites adjacent to the Bellingshausen Sea, precipitation exceeds $1 \mathrm{~m} \mathrm{a}^{-1}$ water equivalent (Peel and Clausen 1982), compared to $0.2 \mathrm{~m} \mathrm{a}^{-1}$ at Filchner Station on Ronne Ice Front in the Weddell Sea and to $0.17 \mathrm{~m} \mathrm{a}^{-1}$ at Ross Ice Front.

\section{ICE-OCEAN INTERACTION}

Glacial melt waters are readily identifiable in our study area by their characteristic melting line on the $T-S$ plane, a line of high linearity and unique, predictable gradient. The northern ice front of George VI Ice Shelf exhibits probably the most convincing verification of Gade's (1979) model, which predicts the characteristic melting line. The same evidence is clearly seen in southern ice-front profiles (Potter and others 1988). The water characteristics at the sea floor are preserved throughout the present section (Figs 3 and 4 ) and are identical with the deepest water on the continental shelf in the western Bellingshausen Sea.

Since only one deep-water station exists for Marguerite Bay, it is impossible to detail how it compares with its southern counterpart as an ice-front environment. However, the $T-S$ structure of water in Marguerite Bay is strikingly similar to that at the ice front itself, and the linear melting characteristic is also observed beneath a surface layer in shallow (about $100 \mathrm{~m}$ depth) parts of the bay (personal communication from J.G. Paren). It is almost certain that melt water is the dominant influence in the top $200 \mathrm{~m}$ in much of the bay and that this fresh-water input contributes to the low surface salinities in the region.

As the sections continue beneath the ice shelf all isolines are depressed. The effect is seen $100-200 \mathrm{~m}$ below the boundary and this is consistent with the glacial melting model of Gade (1979), in which a turbulent sea-water layer with a thickness of the order of $200 \mathrm{~m}$ is expected. In the sections, the basal sill of George VI Ice Shelf is clearly seen to divide the sound into two distinct oceanic regimes. Melt-water mixtures associated with relatively warm, up-welled, sea-water are observed at the southern ice front. The main difference between the northern and southern areas is the "background" water column, which in the south is similar to Bellingshausen sea-water, whereas in the north it shows extensive up-welling of CDW over the whole cross-section of George VI Sound.

The scarcity of good hydrographic stations in our study area to support more conventional glaciological work on George VI Ice Shelf precludes more serious estimates of the possible implications of climatic change for the vulnerable sea-ice interface. Direct measurements near the southern ice front should soon allow melt estimates to be made there, and contribute to a better understanding of the smaller-scale glaciology of the ice shelf.

\section{ACKNOWLEDGEMENTS}

I am grateful to Dr J.G. Paren and Dr K.W. Nicholls for their advice during the preparation of this work.

\section{REFERENCES}

Arctowski, H., and H.R. Mill. 1908. Relations thermiques. In Résultats $d u$ voyage $d u$ S.Y. Belgica. Rapports Scientifiques. Vol. 5. Anvers, Imprimerie J.E. Buschmann.

Deacon, G.E.R. 1937. The hydrology of the Southern Ocean. Discovery Rep., 15, 1-124.

Foldvik, A., T. Gammelsrød, and T. Tørresen. 1985. Circulation and water masses on the southern Weddell Sea shelf. In Jacobs, S.S., ed. Oceanology of the Antarctic continental shelf. Washington, DC, American Geophysical Union, 5-20. (Antarct. Res. Ser., 43.)

Foster, T.D. 1984. The marine environment. In Laws, R.M., ed. Antarctic Ecology. Vol. 2. London, etc., Academic Press, 345-371.

Gade, H.G. 1979. Melting of ice in sea water: a primitive model with application to the Antarctic ice shelf and icebergs. J. Phys, Oceanogr., 9(1), 189-198.

Gill, A.E. 1973. Circulation and bottom water production in the Weddell Sea. Deep-Sea Res., 20(2), 111-140. 
Grigor'yev, Yu.A. 1969. Horizontal circulation of water in the Pacific sector of the Southern Ocean. Probl. Arct. Antarct., 30, 26-35.

Hydrographic Department of the Admiralty. 1984. Chart 3175. Approaches to Graham Land. (Updated 1987.) London, Hydrographic Department of the Admiralty.

Jacobs, S.S. 1985. Oceanographic evidence for land ice/ocean interactions in the Southern Ocean. In Glaciers, Ice Sheets, and Sea Level: Effect of a $\mathrm{CO}_{2}$-induced Climatic Change. Report of a Workshop held in Seattle, Washington, September 13-15 1984. Washington, DC, U.S. Department of Energy, 116-128.

Maslanyj, M.P. 1987. Seismic bedrock depth measurements and the origin of George VI Sound, Antarctic Peninsula. Br. Antarct. Surv. Bull., 75, 51-65.

Peel, D.A., and H.B. Clausen. 1982. Oxygen-isotope and total beta-radioactivity measurements on $10 \mathrm{~m}$ ice cores from the Antarctic Peninsula. J. Glaciol., 28(98), 43-55.

Potter, J.R., J.G. Paren, and J. Loynes. 1984. Glaciological and oceanographic calculations of the mass balance and oxygen isotope ratio of a melting ice shelf. J. Glaciol., 30(105), 161-170.
Potter, J.R., M.H. Talbot, and J.G. Paren, 1988. Oceanic regimes at the ice fronts of George VI Sound, Antarctic Peninsula. Continental Shelf Res., 8(4), 347-362.

Reynolds, J.M. 1981. The distribution of mean annual temperatures in the Antarctic Peninsula. Br. Antarct. Surv. Bull., 54, 123-133.

Schwerdtfeger, W. 1976. Annual temperature and ice condition changes in the Antarctic Peninsula area. Antarct. J. U.S., 11(3), 152.

United States National Oceanographic Data Center. 1983. Oceanographic station data file. Washington, DC, United States National Oceanographic Data Center.

U.S. Navy Hydrographic Office. 1962. Operation Deep Freeze 61. 1960-1961. Marine geophysical investigations. Washington, DC, U.S. Navy Hydrographic Office.

Vanney, J.R., and G.L. Johnson. 1980. General bathymetric chart of the oceans (GEBCO). Sheet 5-18. Fifth edition. Ottawa, Canadian Hydrographic Service.

Weyant, W.S. 1967. The Antarctic atmosphere; climatology of the surface environment. New York, American Geographical Society. (Antarct. Map Folio Ser., 8.) 